\title{
Studies on the Flowering in Marguerite
}

\author{
(Chrysanthemum frutescens L.)
}

\author{
Y. Tsukamoto, K. Fujiwar 4 and M. Kimura \\ (Laboratory of Olericulture and Floriculture, Kyoto Univerity)
}

Marguerite is an elegant cut flower for winter use and is cultivated in warmer regions of Japan. It is one of the important cut flowers, but the amount of its production is limited to a relatively small degree. This limitation in marguerite production seems to be due to disease problems. The production center moves from one region to another every few years. Therefore, growers lack knowledge of the fundamental nature of marguerite flowering. This study deals with the flowering behavior of this plant, which is considered to be a long-day plant.

\section{Materials and Methods}

The experiments were conducted from 1958 through 1963. Marguerite is a semi-hardy perennial, and its flowering continues from winter to early summer in warmer regions. Flowering, then, ceases in mid-summer through late autumn, and resumes in early winter. It begins on the upper branches. This means that flowers initiate earlier on older branches. Therefore, cuttings were taken from lower branches to obtain materials without flower primordia in early through middle autumn when low temperature did not prevail. Cuttings were placed in a $12 \mathrm{~cm}$ clay pot after roots emerged, and then were moved to a room in the Phytotron, where temperature was maintained at $20{ }^{\circ} \mathrm{C}$ and continuous illumination was given until the start of the experiment. After the end of November, the plants were exposed to various experimental conditions. Plant height, number of leaves, budding date and flowering date were recorded. Furthermore, the characteristics of the flower and leaf in every experimental lot were observed.

\section{Results}

Experiment 1. Cuttings were made on October 10, 1958. Each of three young plants was planted in a $12 \mathrm{~cm}$ pot after rooting. The plants were divided into six lots, each lot consisted of ten pots. The lots were exposed to six different conditions using a cool greenhouse and rooms of the Phytotron : long day at $20^{\circ} \mathrm{C}$, short day at $20{ }^{\circ} \mathrm{C}$, long day at $30^{\circ} \mathrm{C}$, short day at $30^{\circ} \mathrm{C}$, long day at temperature of cool greenhouse whose night temperature was maintained above $5{ }^{\circ} \mathrm{C}$, and short day at temperature of cool house. The short day lots were given the natural short day length of winter season, while the long day lots were given continuous illumination. This series of experiments was started on November 28. All plants were pinched on December 23, and three shoots were left to develop on each plant. Plant height, the number of leaves and the number

Received for publication October 16, 1965. 
Table 1. Effects of day-length and temperature upon the flowering and budding in marguerite.

\begin{tabular}{|c|c|c|c|c|c|c|}
\hline Temperature & Day-length & $\begin{array}{l}\text { No. of days to } \\
\text { budding }\end{array}$ & $\begin{array}{l}\text { Stem length at } \\
\text { budding date }\end{array}$ & $\begin{array}{l}\text { No, of days to } \\
\text { flowering }\end{array}$ & $\begin{array}{l}\text { Stem length at } \\
\text { flowering date }\end{array}$ & $\begin{array}{l}\text { No. of } \\
\text { leaves }\end{array}$ \\
\hline $20^{\circ} \mathrm{C}$ & $\begin{array}{l}\text { Long day } \\
\text { Short day }\end{array}$ & $\overline{78.5}$ & $\overline{16} .9 \mathrm{~cm}$ & $\overline{106.5}$ & $\begin{array}{l}* 36.5 \mathrm{~cm} \\
31.0\end{array}$ & $\begin{array}{r}* 56.6 \\
41.1\end{array}$ \\
\hline $30^{\circ} \mathrm{C}$ & $\begin{array}{l}\text { Long day } \\
\text { Short day }\end{array}$ & - & - & - & $\begin{array}{l}* 11.8 \\
* 8.8\end{array}$ & $\begin{array}{l}* 52.1 \\
* 42.7\end{array}$ \\
\hline $\begin{array}{l}\text { Glasshouse } \\
\text { without } \\
\text { heating }\end{array}$ & $\begin{array}{l}\text { Long day } \\
\text { Short day }\end{array}$ & $\begin{array}{l}59.9 \\
67.1\end{array}$ & $\begin{array}{l}20.3 \\
13.4\end{array}$ & $\begin{array}{r}92.5 \\
104.8\end{array}$ & $\begin{array}{l}52.5 \\
39.4\end{array}$ & $\begin{array}{l}20.7 \\
19.1\end{array}$ \\
\hline
\end{tabular}

*: Records were taken on the 98 th day after pinching.

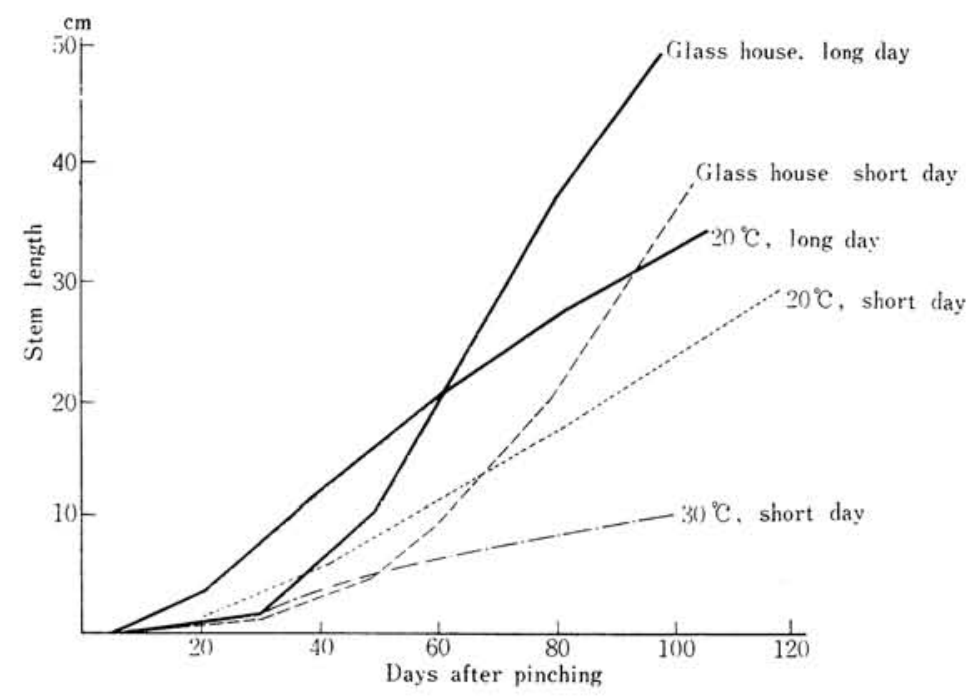

Fig. 1. Elongation of stem in plants under various conditions.

of days to budding or flowering and the stem length at flowering time were recorded 98 days after pinching. These data are shown in Table 1 and Figure 1.

Results are shown on flowering as observed in the lot of $20^{\circ} \mathrm{C}$ short day and in the 2 lots of the cool house. Poor budding resulted in the lot of $20^{\circ} \mathrm{C}$ long day, and the primordia of the flower bud became vegetative. Low temperature caused good flower bud initiation. This fact is clear from the comparison of the number of leaves between the lot of $20^{\circ} \mathrm{C}$ short day and lots of cool house. A high temperature of $30^{\circ} \mathrm{C}$ was inhibitory to the growth and budding regardless of day length. Plant height under long day in the cool house increased as the season advanced beginning at about 60 days after pinching.

Experiment 2. This series of the experiment was conducted to examine the effect of cooling on budding and flowering and to clarify the relationship between the age of the plant at the onset of cooling and the length of the cooling period required for bud formation.

Cuttings were made on September 16, 1958. After rooting, young plants were grown 
in the room of the Phytotron until November 28, when the experiment was started. The tops of all plants were removed at the start, and the first group was moved immediately into a frame where the minimum temperature was maintained at $7-10{ }^{\circ} \mathrm{C}$. The second group was moved into the frame 20 days after pinching, and the third group 40 days after pinching. Plants of each group were exposed to the cool temperature in the frame for $10,20,40$ or 60 days, and then they were returned to the Phytotron room of $20^{\circ} \mathrm{C}$ with natural short day length. Each plant was allowed to develop three shoots. The number of days from pinching to budding, the number of leaves including bracts below the bud, stem length at budding date and percentage of blindness were recorded.

The results are shown in Tables 2 and 3. The data show that the plants of 0 day or 20 days in age required cool temperature over 20 days for bud formation. They did not respond to 10 days of cool temperature. However, the shoots at the age of 0 day, or 20 days after pinching, resulted in high percentage of blindness even though exposed to an adequate amount of cool temperature. A period of 40 days after pinching was necessary for complete flower development. When older plants are exposed to cooling, the number of days from start of cooling to budding is less. As Table 2 shows, the plants which did not differentiate buds during the early part of the experiment, initiated flower buds at the later dates. A similar result was observed in plants of the

Table 2. Distribution of budding in the plants treated with low temperature at various stages of age.

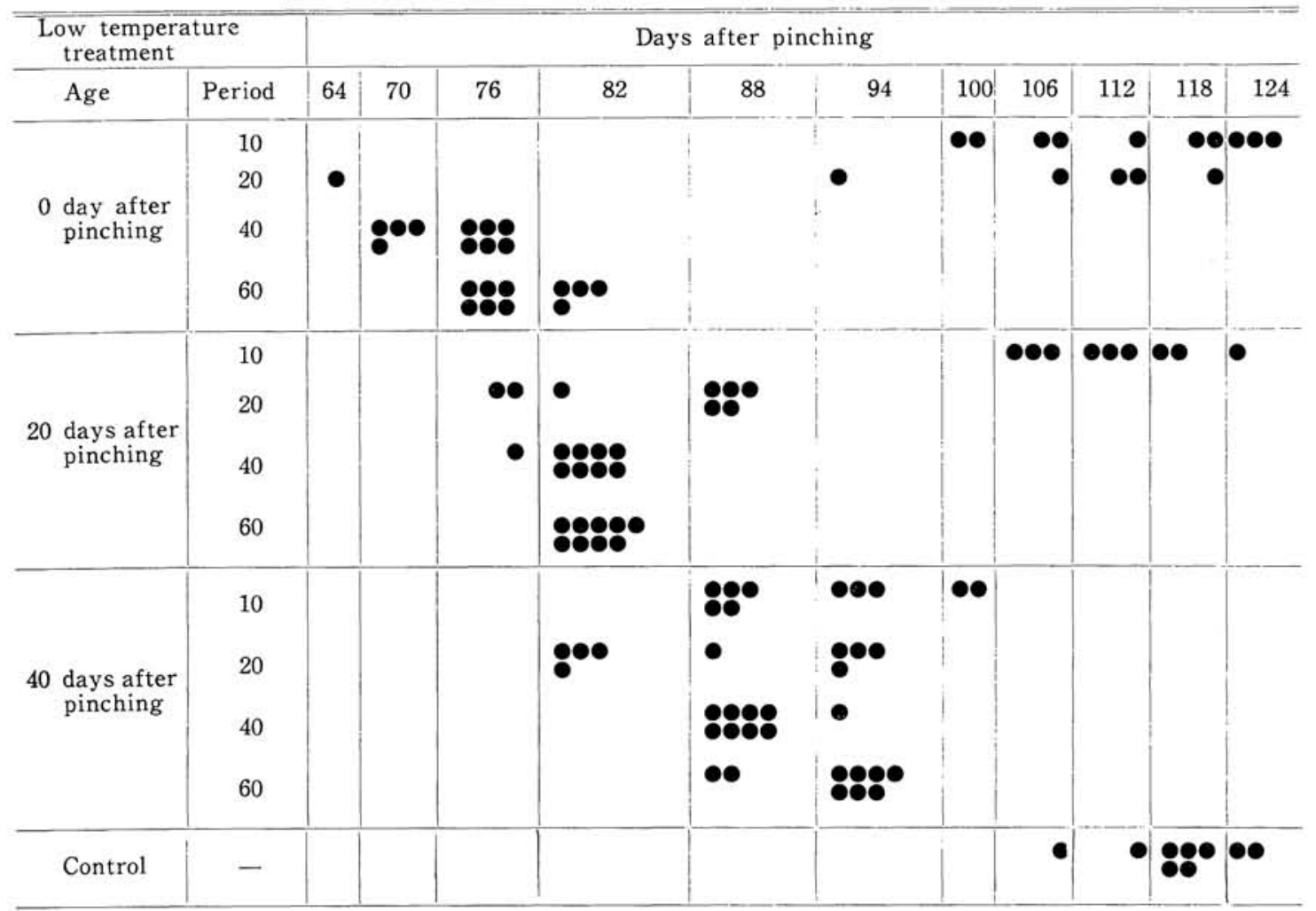


Table 3. Effect of low temperature treatment at various ages of shoot on budding and flowering.

\begin{tabular}{|c|c|c|c|c|c|c|c|}
\hline \multicolumn{2}{|c|}{$\begin{array}{l}\text { Low temperature } \\
\text { treatment }\end{array}$} & \multirow{2}{*}{$\begin{array}{l}\text { No. of } \\
\text { budding } \\
\text { plants }\end{array}$} & \multirow{2}{*}{$\begin{array}{l}\text { No. of } \\
\text { days to } \\
\text { budding }\end{array}$} & \multirow{2}{*}{$\begin{array}{l}\text { Stem length at } \\
\text { budding date }\end{array}$} & \multirow{2}{*}{$\begin{array}{l}\text { No. of } \\
\text { leaves } \\
\text { and bracts }\end{array}$} & \multirow{2}{*}{$\begin{array}{l}\% \text { of } \\
\text { budding } \\
\text { shoots }\end{array}$} & \multirow{2}{*}{$\begin{array}{c}\% \text { of } \\
\text { blindness }\end{array}$} \\
\hline Age & Period & & & & & & \\
\hline \multirow{4}{*}{0 day } & 10 days & $0(10)$ & & & & & \\
\hline & 20 & $1(10)$ & 67 & $12.0 \mathrm{~cm}$ & $20.0+3.0$ & 10.0 & 100 \\
\hline & 40 & $10(10)$ & 75.7 & 12.5 & 19. $1+3.2$ & 100 & 100 \\
\hline & 60 & $10(10)$ & 79.9 & 12.4 & $19.9+2.6$ & 100 & 100 \\
\hline \multirow{4}{*}{20 days } & 10 & $0(9)$ & & & & & \\
\hline & 20 & $8(8)$ & 65.0 & 18.4 & $28.0+3.8$ & 75.0 & 88.9 \\
\hline & 40 & $9(9)$ & 61.3 & 15.8 & $26.7+2.2$ & 100 & 76.9 \\
\hline & 60 & $9(9)$ & 62.0 & 15.0 & $25.7+2.1$ & 100 & 77.8 \\
\hline \multirow{4}{*}{40 days } & 10 & $9(9)$ & 52.7 & 20.9 & $37.4+2.8$ & 92.6 & 0 \\
\hline & 20 & $\exists(9)$ & 48.3 & 19.7 & $34.4+2.4$ & 100 & 0 \\
\hline & 40 & $9(9)$ & 49.3 & 17.8 & $33.9+1.6$ & 100 & 0 \\
\hline & 60 & $9(9)$ & 53.2 & 17.9 & $34.6+1.4$ & 100 & 0 \\
\hline \multicolumn{2}{|c|}{ Control - } & $0(10)$ & - & - & - & - & - \\
\hline
\end{tabular}

( ) shows the number of plants examined.

control lot. The fact is coincident with the result obtained in the $20^{\circ} \mathrm{C}$ lot with the short day-length in experiment 1 .

Experiment 3. This series of experiments was performed to examine the flowering response to constant temperatures or combinations of low and high temperatures during various times under various day-lengths. Cuttings were made on Oct. 12, 1959, and the rooted young plants were allowed to grow in the Phytotron room of $20^{\circ} \mathrm{C}$ under long day-length until December 9. Then all plants, with their tops removed, were included in the experiment. The plants were divided into 3 groups each containing several lots, each of which consisted of 10 plants.

In the first group, plants were placed under 2 different temperature conditions : in a low temperature frame without heat, and in a high temperature greenhouse heated at $20^{\circ} \mathrm{C}$ or above. Plants received $8-, 16-$ or $24-\mathrm{hr}$. day-length in each condition. Number of days from the start of the experiment to the budding or flowering dates, stem length at the budding or flowering dates, number of leaves and flowering or blinding percentage were recorded. The data are shown in Table 4.

In the second group, plants were placed in the same frame used in the first group for 20 or 40 days, and then moved into the high temperature greenhouse, where they were kept until the buds appeared. Temperature treatment for the third group was the reverse of that for the second. Plants were first grown at a high temperature for 20 or 40 days, then moved to the cold frame in which they were kept until the buds became visible. The plants in the second and third groups received 8- or 24-hr. daylength during the temperature treatment period. Therefore, plants were exposed to all possible combinations of day-length and temperature. The same records as those for the first group were taken. The data in Tables 5 and 6 show that low temperature 
Table 4. Flowering response to constant temperature under various day-lengths.

\begin{tabular}{|c|c|c|c|c|c|c|c|c|}
\hline Temperature & Day-length & $\begin{array}{l}\text { No. of } \\
\text { days to } \\
\text { budding }\end{array}$ & $\begin{array}{l}\text { Stem length } \\
\text { at budding } \\
\text { date }\end{array}$ & $\begin{array}{l}\text { No. of } \\
\text { days to } \\
\text { flowering }\end{array}$ & $\begin{array}{l}\text { Stem length } \\
\text { at flowering } \\
\text { date }\end{array}$ & $\begin{array}{l}\text { No. of } \\
\text { leaves } \\
\text { and } \\
\text { bracts }\end{array}$ & $\begin{array}{l}\% \text { of } \\
\text { budding } \\
\text { shoots }\end{array}$ & $\begin{array}{l}\% \text { of } \\
\text { blindness }\end{array}$ \\
\hline \multirow{3}{*}{ Low } & $8 \mathrm{~h}$. & 61.9 & $10.0 \mathrm{~cm}$ & 103.8 & $35.4 \mathrm{~cm}$ & $20.5+2.2$ & 100 & 0 \\
\hline & 16 & 52.6 & 11.1 & 87.4 & 30.7 & $21.3+1.1$ & 100 & 0 \\
\hline & 24 & 74.4 & 16. 1 & 102.6 & 38.5 & $29.6+1.2$ & 60 & 0 \\
\hline \multirow{3}{*}{ High } & 8 & 124.7 & 26.8 & - & - & $53.7+2.4$ & 92 & 56 \\
\hline & 16 & - & - & - & - & - & - & - \\
\hline & 24 & - & - & - & - & - & - & - \\
\hline
\end{tabular}

Table 5. Flowering response to combination of low and high temperature treatments.

\begin{tabular}{|c|c|c|c|c|c|c|c|c|}
\hline \multicolumn{2}{|c|}{ Low temperature } & \multirow{2}{*}{$\begin{array}{l}\text { High } \\
\text { temperature } \\
\text { day-length }\end{array}$} & \multirow{2}{*}{$\begin{array}{l}\text { No. of } \\
\text { days to } \\
\text { budding }\end{array}$} & \multirow{2}{*}{$\begin{array}{l}\text { Stem length } \\
\text { at budding } \\
\text { date }\end{array}$} & \multirow{2}{*}{$\begin{array}{l}\text { No. of } \\
\text { leaves and } \\
\text { bracts }\end{array}$} & \multirow{2}{*}{$\begin{array}{l}\text { No. of } \\
\text { plants } \\
\text { budded }\end{array}$} & \multirow{2}{*}{$\begin{array}{l}\% \text { of } \\
\text { budding } \\
\text { shoots }\end{array}$} & \multirow{2}{*}{$\begin{array}{l}\% \text { of } \\
\text { blindness }\end{array}$} \\
\hline Period & Day-length & & & & & & & \\
\hline \multirow{4}{*}{20 days } & \multirow{2}{*}{$8 \mathrm{~h}}$. & $8 \mathrm{~h}$. & 67.6 & 12.3 & $25.2+4.6$ & 5 & 33.3 & 62.5 \\
\hline & & $24 \mathrm{~h}$. & 53.7 & 9.2 & $21.0+2.4$ & 7 & 40.0 & 91.7 \\
\hline & \multirow{2}{*}{$24 \mathrm{~h}$. } & $8 \mathrm{~h}$. & 64.0 & 11.3 & $24.0+4.0$ & 2 & 7.2 & 100 \\
\hline & & $24 \mathrm{~h}$. & 52.0 & 7.0 & $21.0+2.0$ & 1 & 3.3 & 100 \\
\hline \multirow{4}{*}{40 days } & \multirow{2}{*}{$8 \mathrm{~h}}$. & 8 h. & 60.1 & 11.8 & $21.6+2.2$ & 10 & 100 & 86.7 \\
\hline & & $24 \mathrm{~h}$. & 57.1 & 10.1 & $20.7+2.0$ & 10 & 90 & 85.2 \\
\hline & \multirow{2}{*}{$24 \mathrm{~h}$. } & $8 \mathrm{~h}$. & 40.0 & 11.0 & $17.0+2.0$ & 1 & 3. 3 & 100 \\
\hline & & $24 \mathrm{~h}$. & 49.0 & 10.5 & $19.0+3.0$ & 1 & 6.7 & 100 \\
\hline
\end{tabular}

Table 6. Flowering response to combination of high and low temperature treatments.

\begin{tabular}{|c|c|c|c|c|c|c|c|c|}
\hline \multicolumn{2}{|c|}{ High temperature } & \multirow{2}{*}{$\begin{array}{c}\text { Low } \\
\text { temperature } \\
\text { day-length }\end{array}$} & \multirow{2}{*}{$\begin{array}{l}\text { No. of } \\
\text { days to } \\
\text { budding }\end{array}$} & \multirow{2}{*}{$\begin{array}{l}\text { Stem length } \\
\text { at budding } \\
\text { date }\end{array}$} & \multirow{2}{*}{$\begin{array}{l}\text { No. of } \\
\text { leaves and } \\
\text { bracts }\end{array}$} & \multirow{2}{*}{$\begin{array}{l}\text { No. of } \\
\text { plants } \\
\text { budded }\end{array}$} & \multirow{2}{*}{$\begin{array}{l}\% \text { of } \\
\text { budding } \\
\text { shoots }\end{array}$} & \multirow{2}{*}{$\begin{array}{l}\% \text { of } \\
\text { blindness. }\end{array}$} \\
\hline Period & Day-length & & & & & & & \\
\hline \multirow{4}{*}{20 days } & & 8 h. & 74.8 & $15.4 \mathrm{~cm}$ & $29.9+1.7$ & 10 & 100 & 0 \\
\hline & & $24 \mathrm{~h}$. & 76.0 & 17.4 & $34.4+1.2$ & 10 & 63.3 & 0 \\
\hline & \multirow{2}{*}{$24 \mathrm{~h}$. } & $8 \mathrm{~h}$. & 72.7 & 14.2 & $30.9+1.7$ & 10 & 96.7 & 0 \\
\hline & & $24 \mathrm{~h}$. & 73. 0 & 17.7 & $33.5+1.3$ & 10 & 66.7 & 0 \\
\hline \multirow{4}{*}{40 days } & \multirow{2}{*}{$8 \mathrm{~h}}$. & 8 h. & 83.3 & 14.3 & $32.7+1.9$ & 10 & 93.3 & 0 \\
\hline & & $24 \mathrm{~h}$. & 76.9 & 14.5 & $33.3+1.2$ & 10 & 93.3 & 0 \\
\hline & \multirow{2}{*}{$24 \mathrm{~h}}$. & 8 h. & 84.4 & 17.0 & $38.3+1.7$ & 10 & 96.3 & 0 \\
\hline & & $24 \mathrm{~h}$. & 80.5 & 19. 2 & $38.5+1.1$ & 10 & 56.7 & 0 \\
\hline
\end{tabular}

effectively induces flower bud initiation. Short day-length enhances this tendency regardless of the difference in temperatures. This fact is particularly clear in the data in Table 4. A comparison between the data in Tables 5 and 6 shows that a shorter exposure to the low temperature gives poorer flowering response than a longer exposure. In this case, short day-length gives accent to the trend.

The limited application of low temperature resulted in a high percentage of blindness as shown in Table 5. On the contrary, longer exposure to the low temperature resulted in no blindness. But, there is a discrepancy between the result in the $20^{\circ} \mathrm{C}$ short day lot (Table 1) and that in the high temperature with the short day-length lot (Table 3 ). 
Each plant developed three shoots, all of which initiated flower buds under favorable condition. However, some of the shoots remained vegetative under unfavorable condition. These facts account for the differences in percentages of budding shoots in the tables.

Furthermore, buds developed into complete flowers under favorable condition, while they discontinued development into complete flowers when placed under unfavorable condition. These results are shown in the tables by the percentage of blindness.

Experiment 4. The previous experiments suggest that low temperature treatment for more than 20 days given to the plant at the age over 20 days after potting is able to induce the flower bud formation and the flower bud development. Therefore, in this series of experiments, low temperature for 20 days was applied, and the effect of daylength during or after the temperature treatment was examined. Cuttings were made on September 5, 1962, and they were potted on October 20 after rooting and were kept in the Phytotron room. Then, the tops of the plants were removed on November 29. The treatment was begun on December 28, 30 days after pinching, using cold frames where the prevailing temperature was maintained low but not below $10{ }^{\circ} \mathrm{C}$. Plants in the frame received a short day length of 8 hours (day light) or a long day-length of 16 hours ( $8 \mathrm{hr}$. day light $+8 \mathrm{hr}$. illumination with incandescent lamps). Each group was returned into the Phytotron room of $20^{\circ} \mathrm{C}$, and was divided into two lots of short daylength $(8 \mathrm{hrs}$.) and long day-length $(16 \mathrm{hrs}$.). Thus, four lots were grown under different combinations of day-length during and after the low temperature treatment. These four lots are designated as SD-LD, SD-SD, LD-LD and LD-SD. Budding dates, flowering dates, number of leaves and plant heights in the four lots were recorded. The results are shown in Figs. 2 and 3, and Table 7.

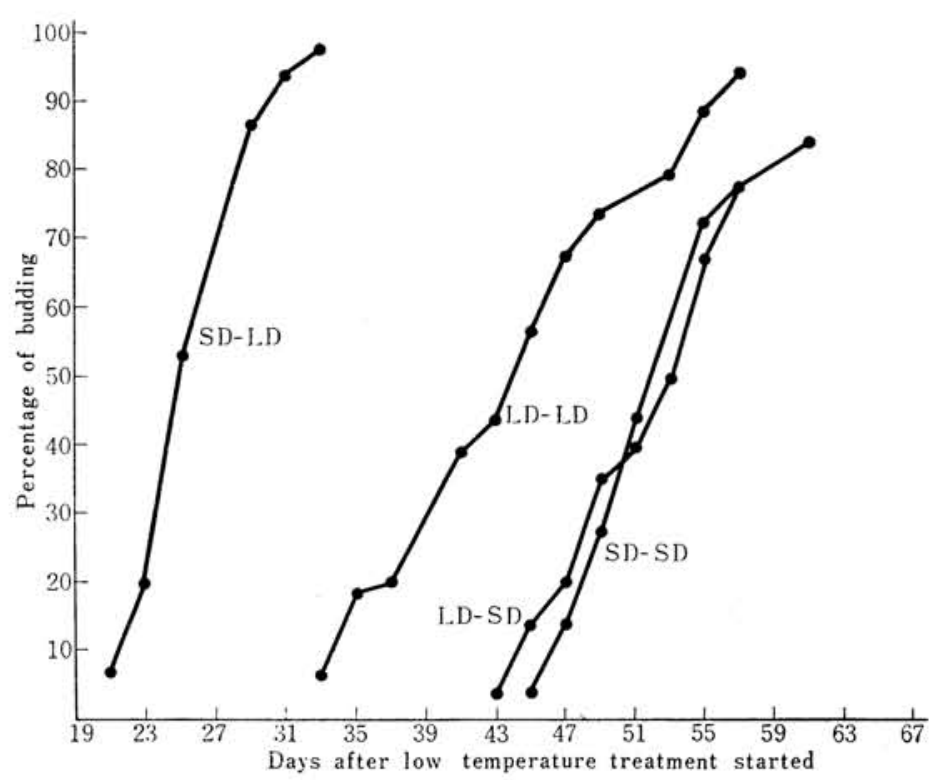

Fig. 2. Effect of day-length during low temperature treatment on budding. 


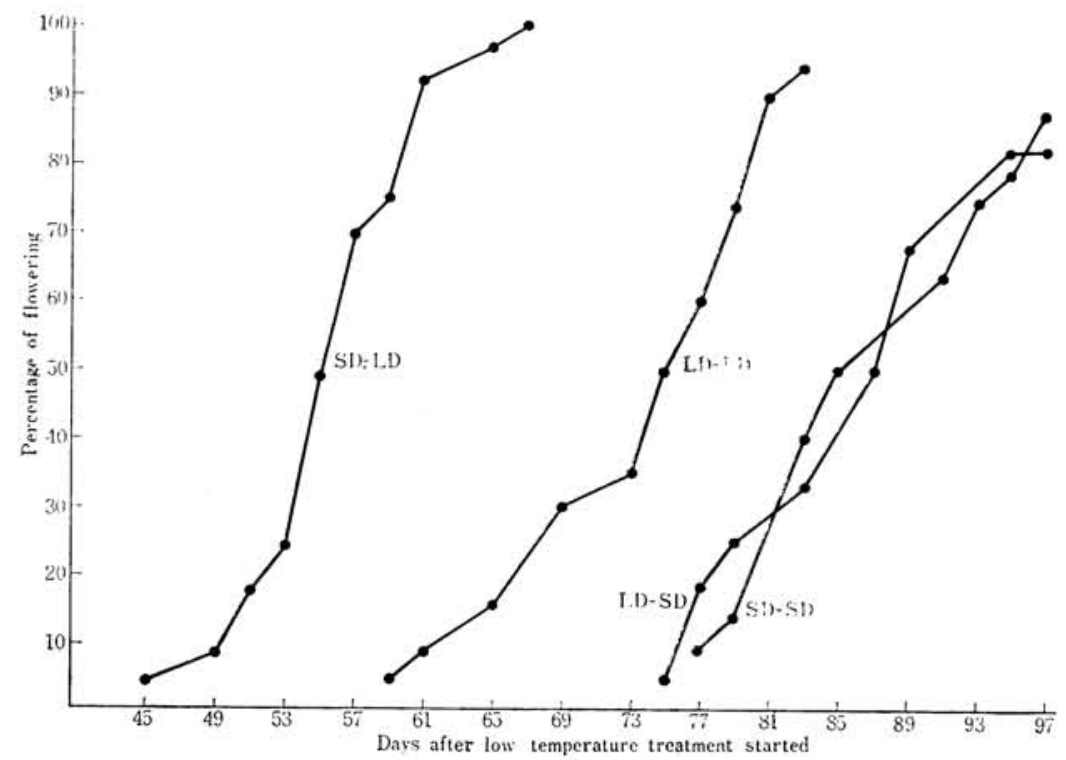

Fig. 3. Effect of day-length during low temperature treatment on flowering,

Table 7. Effects of day-length during and after the low temperature treatment on the number of leaves and stem length in marguerite.

\begin{tabular}{c|c|c|c|c} 
Lot & SD-SD & LD-SD & SD-LD & LD-LD \\
\hline $\begin{array}{c}\text { Number of } \\
\text { leaves }\end{array}$ & 53.5 & 57.8 & 52.9 & 58.6 \\
\hline $\begin{array}{c}\text { Stem length } \\
(\mathrm{cm})\end{array}$ & 16.0 & 17.8 & 32.5 & 37.5 \\
\hline
\end{tabular}

Budding was earliest in the SD-LD lot, and was followed by that in the LD-LD, LD-SD and the SD-SD lots. The flowering results were quite similar to those of budding. However, there was little difference between LD-SD and SD-SD lot, and some blind shoots were observed in these lots. The average height at the flowering stage was shorter in the SD-SD and LD-SD lot than in the other two. On the other hand, the number of leaves was smaller in SD-SD and SD-LD lot than in the other two. These results suggest that short day-length during the low temperature treatment enhanced the flower bud initiation, while long day-length during the growing period after the low temperature treatment affected elongation. There was a marked difference in the plant form between the short day and the long day lots. The plants under short day-length showed very shortened internodes and had rosette-like and dark green leaves, while the plants under long day-length showed long internodes and light green leaves.

Experiment 5. The results mentioned above seem to suggest that the low temperature is the main cause for the flower bud formation in marguerite, but there remains the possibility that the short day-length might have some effects. Therefore, the effect of short day-length on flowering was investigated without low temperature. In order to avoid subjecting to cool temperature cuttings were made on August 15, 1963, and were kept in the Phytotron room of $20^{\circ} \mathrm{C}$ under long day-length $(10 \mathrm{hr}$. day light $+14 \mathrm{hr}$. illumination with incandescent and fluorescent lamps) until the beginning of the experiment. Plants were divided into seven groups, and each group containing eight plants was given short day (10 hrs.) treatment for $20,40,60,80$ or 100 days from October 2 . 
They were returned to the long day exposure after each treatment. Besides these five groups, two other groups were set up. One was the long day control which was for 150 days after the commencement of the experiment, and the other was the short day control. These two groups contained extra plants which were to be used for dissections. The observation made on the flower primordia is shown in Table 8 , and the

Table 8. Flower bud differentiation of marguerite at $20^{\circ} \mathrm{C}$.

\begin{tabular}{c|c}
\hline $\begin{array}{c}\text { Days afetr the start of } \\
\text { short day treatment }\end{array}$ & Flower bud \\
\hline 0 & --+- \\
20 & ----- \\
40 & -- \pm \pm+ \\
60 & \pm \pm+++ \\
80 & +++++ \\
\hline Long day (150 days) & --+-- \\
\hline
\end{tabular}

- : Vegetative

$\pm:$ Flower bud initiation

+ : Visible flower bud results of flowering response in Table 9, and Figs. 4 and 5. The data show that the flower primordia initiated as late as the 40 th day of the short day treatment, but flower development was confirmed only in the plants treated with short day for 80 or 100 days. The plants of these two groups initiated the flower primordia under short day condition and developed them under long day conditions. Even if the primordia emerged on the 40 th day of the treatment, they could not reach the final stage of flower development on the 150 th day of the treatment. The data on

Table 9. Flowering response to the short day treatment at $20^{\circ} \mathrm{C}$.

\begin{tabular}{|c|c|c|c|c|c|c|}
\hline Treatment & $\begin{array}{l}\text { No. of } \\
\text { leaves }\end{array}$ & $\begin{array}{r}\text { Stem } \\
\text { length }\end{array}$ & $\begin{array}{l}\text { No. of budded } \\
\text { plants }\end{array}$ & $\begin{array}{l}\% \text { of } \\
\text { budding }\end{array}$ & $\begin{array}{l}\% \text { of budding } \\
\text { shoots }\end{array}$ & $\begin{array}{l}\% \text { of } \\
\text { blindness }\end{array}$ \\
\hline $\begin{array}{lrl}\text { SD } & 150 & \text { days } \\
\text { SD } & 20 & \prime \prime \\
\text { SD } & 40 & \prime \prime \\
\text { SD } & 60 & \prime \prime \\
\text { SD } & 80 & \prime \prime \\
\text { SD } & 100 & \prime \prime \\
\text { LD } & 150 & \prime \prime\end{array}$ & $\begin{array}{l}58.5 \\
85.1 \\
52.2 \\
51.4 \\
57.2 \\
57.9 \\
89.6\end{array}$ & \begin{tabular}{l|}
$14.0 \mathrm{~cm}$ \\
28.2 \\
23.9 \\
24.4 \\
23.0 \\
23.7 \\
27.4
\end{tabular} & $\begin{array}{l}0 \\
0 \\
0 \\
0 \\
7 \\
8 \\
0\end{array}$ & $\begin{array}{c}0 \\
0 \\
0 \\
0 \\
87.5 \\
100 \\
0\end{array}$ & $\begin{array}{c}0 \\
0 \\
0 \\
0 \\
70.8 \\
83.3 \\
0\end{array}$ & $\begin{array}{l}0 \\
0 \\
0 \\
0 \\
0 \\
0 \\
0\end{array}$ \\
\hline
\end{tabular}

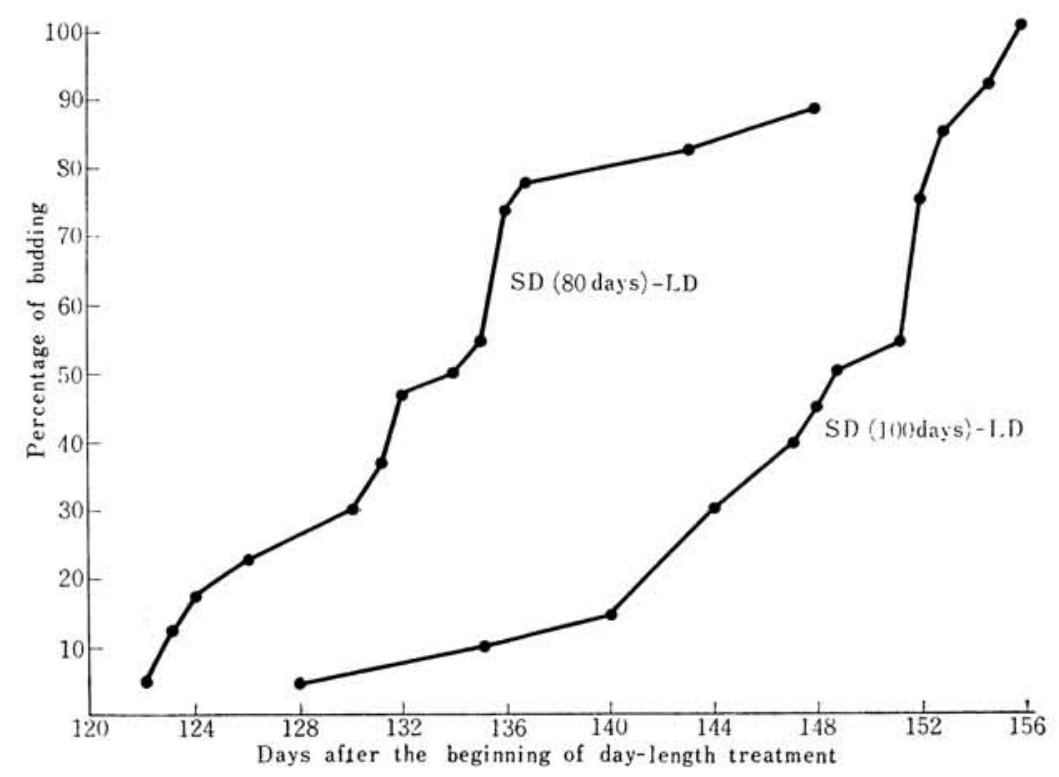

Fig. 4. Effect of short day treatment over a long period followed by long day on budding 


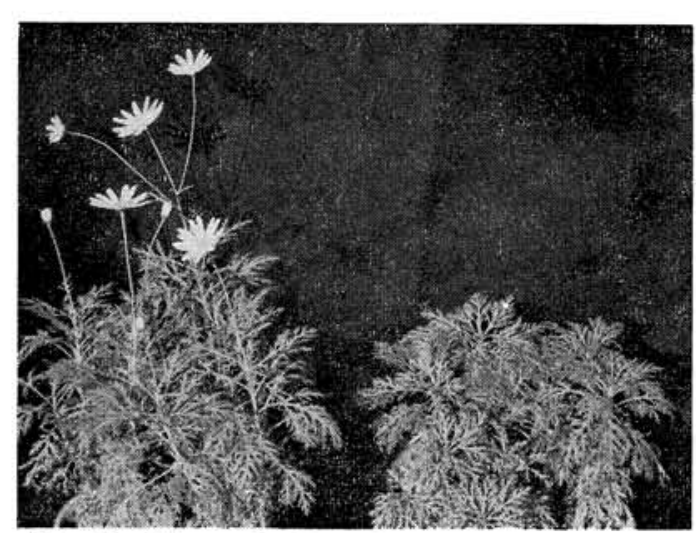

Fig. 5. Effect of short-day treatment over a long period on flowering.

Left : 100 dyas of short-day followed by long-day

Right : 150 days of short-day, internodes showing no elongation the lot of short day control shown in Table 9 indicate this fact.

Experiment 6. The problem studied in this series of experiments is how gibberellin (gibberellic acid) affects the flower bud formation in plants kept under non-inductive condition at $20^{\circ} \mathrm{C}$ or in plants given a slight induction by short day treatment for 50 days. Cuttings were made on September 23,1962 , and rooted cuttings were potted on October 20. Three shoots were developed on each plant after pinching on November 29. Plants were kept about one month in the Phytotron room of $20^{\circ} \mathrm{C}$ under continuous illumination On December 28, half of the plants were moved into short day exposure $(10 \mathrm{hrs}$.) and kept there for 50 days. Then the plants treated with short day were returned to the long day condition (continuous illumination). Plants of these two groups were divided into three lots each. Gibberellin solutions of 0,25 and $50 \mathrm{ppm}$ were applied to the three lots, respectively six times at five day intervals beginning on the 80 th day after pinching. Each lot consisted of 12 plants. The results are shown in Table 10. As the results show, gibberellin accelerated the budding of plants whose flower primordia were slightly induced by short day during the 50 days, while it did not affect the budding of plants placed under non-inductive condition. However, flower buds formed by gibberellin application resulted in blindness. This indicates that the role of gibberellin in flower formation of marguerite is very weak though the higher dose had a little stronger effect. The higher the dose of gibberellin the longer the stem grew.

\section{Discussion}

The marguerite is a plant originated in the Canary Island. This fact suggests that the plant cannot stand severe low temperature but needs some cool temperatures for

Table 10. Effects of gibberellin on the flowering of marguerite (120 days after pinching).

\begin{tabular}{|c|c|c|c|c|c|c|}
\hline \multicolumn{2}{|c|}{ Treatment } & $\begin{array}{l}\text { No. of } \\
\text { leaves }\end{array}$ & $\begin{array}{r}\text { Stem } \\
\text { length }\end{array}$ & $\begin{array}{l}\text { No. of buddied } \\
\text { plants }\end{array}$ & $\begin{array}{l}\% \text { of budd ng } \\
\text { shoot }\end{array}$ & $\begin{array}{l}\% \text { of } \\
\text { blindness }\end{array}$ \\
\hline $\begin{array}{l}\text { LD after } \\
50 \text { days SD }\end{array}$ & $\begin{aligned} & 0 \text { ppm } \\
\text { GA } & 25 \\
50 & \end{aligned}$ & $\begin{array}{l}46 \\
45 \\
43\end{array}$ & $\begin{array}{l}11.4 \mathrm{~cm} \\
16.7 \\
24.2\end{array}$ & $\begin{array}{l}3(12) \\
5(12) \\
8(12)\end{array}$ & $\begin{array}{l}25 \\
39 \\
56\end{array}$ & $\begin{array}{l}100 \\
100 \\
100\end{array}$ \\
\hline LD & 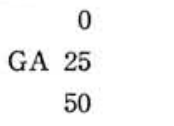 & $\begin{array}{l}67 \\
70 \\
68\end{array}$ & $\begin{array}{l}18.8 \\
24.5 \\
29.8\end{array}$ & $\begin{array}{ll}0 & (12) \\
0 & (12) \\
0 & (12)\end{array}$ & $\begin{array}{l}- \\
-\end{array}$ & $\begin{array}{l}- \\
- \\
-\end{array}$ \\
\hline
\end{tabular}

( ) shows the number of plants examined. 
flower bud formation. The results in experiment 1 through experiment 4 support. this presumption. Though cool temperature is the main factor in flower formation, short day-length is also effective. The plants initiated flower buds when they were grown under short day conditions of over 60 days at $20^{\circ} \mathrm{C}$ (experiment 5), while the plants in the same series, but placed under long day condition at $20^{\circ} \mathrm{C}$ did not initiate buds within the 150 days in the experiment. Therefore, the flowering character of this plant may require cool temperature and a short day. This characteristic seems similar to that of the Christmas cactus, though the latter is able to initiate buds even at $30^{\circ} \mathrm{C}$ under short day (RüNGER 1961). The interaction between temperature and daylength was confirmed in experiment 3 . If the plants were exposed to cool temperature for 40 days, short day-length of $8 \mathrm{hrs}$. markedly affected budding, while long daylength of $24 \mathrm{hrs}$. inhibited the budding. The data in Table 5 show that the effect of temperature is greater than that of day-length, though the two factors are acting synergistically. If the plants had received low temperature during a sufficient period of time, they showed a high percentage of budding shoots and no blindness (Table 6). There are other plants which show the flowering behavior of the same category as this plant: for example, bromegrass, Christmas cactus and strawberry. But some differences were recognized among them. Further, some plants have been shown to be SLD plants in recent years. Marguerite shows the nature like the SLD plant (Table 7 ), but in the strict sense of the word it is not, but is related. A similar fact was reported by Dooneneos (1959) with China aster, although the latter plant has a LSD plant-like nature.

The phenomenon of devernalization in perennial plants was reported by ScHwABE (1951) using chrysanthemum. Marguerite, though a perennial plant, has not yet been studied with regard to its devernalization. Cuttings taken from the mother plant, which re-elongated after the end of flowering, continued the vegetative growth, if they had not been given a low temperature under long day-length (Table 1 and 4). This means that the mother plants were devernalized due to certain factors. When the rooted cuttings were exposed to low temperature, their age seems to play an important role in bud formation. As data in Table 3 show, a plant of young age needs low temperature of longer period for flower bud formation, while a plant of older age initiated the flower buds even when exposed to low temperatures for only 10 days. The relationship between low temperature requirement and the age of plant was studied by Wellensiek $(1958,1963)$ with Lunaria biennis and Cheiranthus Alloionii. The results in marguerite in this study are fundamentally in agreement with those of WELLENSIEK.

Further, the relationship between vernalization and photoperiodism was also discussed

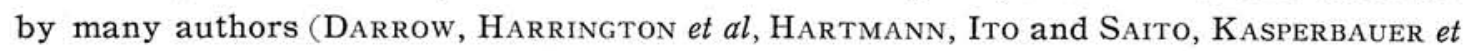
$a l$, Nitsch and Went, Rünger,Samman and Langhans,Smeets and Kronenberg, Wellensiek, etc.) for many plants. The author also reported one case that long days given during vernalization enhanced the flowering of the stock plant (Mathiola incana). In this case, long day-length acted synergetically with the low temperature. This was true in the case of marguerite. The promoting effect of gibberellin for bud formation was rec- 
ognized, but it was quite weak (Table 10). The cases in which gibberellin do not play a decided role in flower formation have been demonstrated in many plants. Marguerite seems to be one of such plants, but the results were so few in number that further experiments are necessary for a definite conclusion to be drawn on the effect of gibberellin.

As discussed above, marguerite is a cold requiring plant in a relative sense, and behaves like a short-long-day plant in the flowering response. This basic nature will have to be paid attention in the practice of cut flower production, especially during the forcing in winter.

\section{Summary}

1) Marguerite is a plant requiring cold temperature for flower formation. Rooted cuttings do not initiate flower buds if they are kept at high temperature such as $30{ }^{\circ} \mathrm{C}$ regardless of the difference in day-length, but they initiate flower buds at $20^{\circ} \mathrm{C}$ with short day-length.

2) Cold temperature is the main cause for flower bud formation, but short daylength also enhances it to a less degree.

3) Flower bud differentiation occurs at $20^{\circ} \mathrm{C}$ under short day condition of more than 40 days.

4) Long day-length promotes flowering better after low temperature treatment than after short day-length.

5) Gibberellin effects, to a slight degree, the flowering of the plant which has received short day-length for 50 days.

\section{Literature cited}

1. BARENDSE, G.W.M. 1963. Devernalization in Cheiranthus Allionii. Proc. Kon. Ned. Akad. Wet. C. $66: 183 \sim 188$.

2. ChOUARD, P. 1957. Le journée courte ou lácide gibberellique comme succédanés du froid pour la vernalization d'une plante vivace en rosette, le Scabiosa succia L. Compte Rendu Acad. Sci. France $245: 2520 \sim 2522$.

3. CHOUARD, P. 1960. Vernalization and its relations to dormancy. Ann. Rev. Plant Physiology $11: 191 \sim 227$.

4. DARROW, G.M. 1937. Interrelation of temperature and photoperiodism in the production of fruit-bud and runners in the strawberry. Proc. Amer. Soc. Hort. Sci. $34: 360 \sim 363$.

5. DOORENBOS, J. 1959. Response of china aster to day-length and gibberellic acid. Euphytica $8: 69 \sim 75$.

6. Doorenbos, J. and P.C.Riemens. 1959. Effect of vernalization and day-length on number and shape of leaves in chicory and endive. Acta Botanica Neer. 8:63 67.

7. GOTT, M.B., F.G. GREgORY, and O.N.PURVIS. 1955. Studies in vernalization of cereals XIII.
Photoperiodic control of stages in flowering between initiation and ear formation in vernalized and unvernalized Petkus winter rye. Ann. Bot. $73: 87 \sim 126$.

8. HARRINGTON, J.F., K.VERKER, and J. DOORENBOS. 1959. Interaction of vernalization, photoperiod and light intensity in floral initiation of endive. Neth. J. Agr. Sci. $7: 68 \sim 74$.

9. HARTMANN, H. T. 1947. The influence of temperature on the photoperiodic response of several strawberry varieties grown under controlled environment conditions. Proc. Amer. Soc. Hort. Sci. $50: 243 \sim 245$.

10. ITO, H. and T.Saito. 1962. Studies on the flower formation in the strawberry plants. I. Effects of temperature and photoperiod on the flower formation. Tohoku Jour. Agr. Res. $13: 191 \sim 203$.

11. Kasperbauer, M. J., F. P. Gardner, and W.E. LOOMIS, 1962. Interaction of photoperiod and vernalization in flowering of sweet clover (Melilotus). Plant Physiol. $37:$ 165 170.

12. LANG, A. and E. ReINHARD. 1961. Gibberellins and flower formation. Gibberellins $71 \sim 79$. 
13. MiCHNiEwiCZ, M. and A. LANG. 1962. Effect of nine different gibberellins on stem elongation and flower formation in cold-requiring and photoperiodic plants grown under noninductive conditions. Planta $58: 549 \sim 563$.

14. NeweLL, L.C. 1951. Controlled life cycles of Bromegrass, Bromus inermis LEYSS., used in improvement. Agron. Jour. 43: 417 424.

15. NitsCH, J.P. and F.W.WENT. 1959. The induction of flowering in Xanthium pensylvanicum under long days. Withrow R.B.: Photoperi odism and related phenomena in plants and animals $311 \sim 314$.

16. RÜNGER, W. 1961. Über den Einfluss der Temperatur und der Tageslänge auf die Blütenbildung von Zygocactus, Weihnachtsfreude. Gartenbauwiss. $26: 529 \sim 536$.

17. RÜNGER, W. 1962. Über den Einfluss täglich und einmal wechselnder Temperatur auf die Blütenbildung von Euphorbia milii DESM. Gartenbauwiss. $27: 119 \sim 126$.

18. SAMman, Y. and R. W. LANGHANS. 1962. Interactions of temperature and photoperiodism in Chrysanthemum morifolium. Advances in horticultural science and their applications $2: 400 \sim 411$.

19. SCHWABE, W. W. 1950. Factors controlling flowering of the Chrysanthemum. I. The effects of photoperiod and temporary chilling. J. Exp. Bot. $1: 329 \sim 343$.

20. SCHWABE, W. W. 1957. Factors controlling flowering in the Chrysanthemum. II. Daylength effects on the further development of inflorescence buds and their experimental reversal and modification. J. Exp. Bot. $2: 223$ $\sim 237$.

21. Smeets, L. and H. G. KronenberG. 1955. Runner formation of strawberry plants in autumn and winter. Euphytica $4: 53 \sim 57$.

22. SMith, C.R.Z.., SoczEK, and W.B.Collins 1961. Flowering and fruiting of strawberries in relation to gibberellins. Gibberellins $109 \sim 115$.

23. TsUKAмото, Y. and K. Konishi. 1960. Effect of light during vernalization on flowering of stocks (Mathiola incana). Jour. Hort. Asso. Japan. $29: 70 \sim 75$

24. WELLENSIEK, S.J. 1958. Vernalization and age in Lunaria biennis Proc. Kon. Ned. Akad. Wet. C. $61: 561 \sim 571$.

25. WELLENSIEK, S.J. 1960. Flower formation in Campanula medium. Mede. Landbou. Wageningen, Nederland 60(7): 1 18.

26. WellensieK, S.J. 1960. Stem elongation and flower initiation. Proc. Kon. Ned. Akad. Wet. C. $63: 159 \sim 166$.

27. WELLENSIEK,S.J. and G.W.M.BARENDSE. 1963. Flower-formation in Cheiranthus Allionti. Proc. Kon. Ned. Akad. Wet. C. 66:123 131.

28. WELlENSIEK, S. J. and M. K. HigazY. 1961 The juvenil phase for flowering in Lunaria biennis. Proc. Kon. Ned. Akad. Wet. C. 64 : $458 \sim 463$.

29. ZeEvaART, J.A.D. and A. LANG. 1962. The relationship between gibberellin and floral stimulus in Bryophyllum daigremontianum. Planta $58: 531 \sim 542$.

\title{
マーガレット (Chrysanthemum frutescens L.) の開花に関する研究
}

\author{
塚 本 洋太郎・富士原 健三・木村 雅 行 \\ (京都大学農学部)
}

\begin{abstract}
摘
要

マーガレットの挿芽苗を秋に準借し，低温にあてない よ5にフアイトトロンの $20^{\circ} \mathrm{C}$ 室で市て, 秋末に摘心し で1株 3 本立にしたものを異なつた温度, 日長の条件に おいて開花反応を調べた。るし， $30^{\circ} \mathrm{C}$ に続けて特けば, 日長の差に関係なく発らいしないが, $20^{\circ} \mathrm{C}$ では短日に よつて花芽形成が行なわれる。短日の期間が 100 日にな ると長日に移しても $100 \%$ 発らいするが，短日期間が 30 日であると $90 \%$ 以下に低下する。解剖してみた場合 さ, 短日 40 日後長日にもどした区でも花芽は分化して いる。

花芽形成に最も強く影響するすのは低温で，摘心後 20 日を経た苗に $10^{\circ} \mathrm{C}$ 程度の低温を 40 日以上あたえると

$100 \%$ 発らいする。しかし，完全に開花させるためには 苗令 40 日になつたものを用いねばならない。その場合, 低温期間は10日でもじゆうらんである。

低温処理中の日長を長日（18 時間）と短日（8時間）

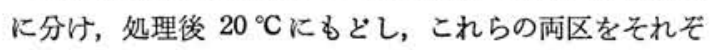
れ 2 つ分けて長日と短日に蛙いたが，短日一長日の組 合せが最も早く発らい, 開花し, 短日一短日の組合せは 最す幄れた。すなわち, マーガレットは短長日植物に似 た傾向を示し, 花芽分化後は長日が促進的である。 $20^{\circ} \mathrm{C}$ に颃いて短日を 50 日与えたものにジベレリンを散布し たが, 発らいは促進されても開花せず, ブラインドにな つた。
\end{abstract}

